\title{
Explanandum teorie vědomí: marné hledání konsenzu?
}

\author{
Tomáš Marvan \\ Filosofický ústav \\ Akademie věd České Republiky \\ Jilská 1, 11000 Praha 1 \\ marvan@flu.cas.cz
}

\begin{abstract}
Text kriticky hodnotí tvrzení o pojmu fenomenálního vědomí, která jsou obsažena v šesté kapitole knihy Tomáše Hříbka Jaké to je, nebo o čem to je? Mým východiskem je teze Erica Schwitzgebela, že fenomenální vědomí můžeme definovat natolik neutrálně a minimalisticky, že se na jeho existenci mohou shodnout i teoretikové vědomí z velmi rozdílných táborů. Hříbek tento názor nesdílí, snažím se ale ukázat, že na základě lichých argumentů. Značnou pozornost v textu věnuji názorům Daniela Dennetta na podstatu vědomí, především pak ,iluzionismu“ jakožto teorii vědomí. Ten pokládám za teorii se značně nejasným obsahem a navrhuji, aby se o něm ve filozofii vědomí vedly soustředěné diskuze.
\end{abstract}

Tomáš Hříbek v úvodu šesté kapitoly své knihy Jaké to je, nebo o čem to je $?^{1}$ konstatuje, že současné teorie vědomí nenacházejí shodu ohledně svého společného explananda. Zatímco většina autorů za toto explanandum pokládá fenomenální vědomí, Daniel Dennett naopak tento pojem zpochybnil a Hř́́bek pak jeho námitky dopracoval do všeobsažné kritiky. Pojem fenomenálního vědomí (a souvisejících pojmů jako je fenomenální charakter, fenomenologie apod.) je podle Hř́ibka bezobsažný. Dokazovat to mají rozpory v textech autorů, kteří se k němu vyjadřují. Hříbek považuje možnost shodnout se na neutrálním explanandu s tradičněji orientovanými teoretiky za prakticky vyloučenou, a navrhuje proto pojem fenomenálního vědomí zcela opustit a pro teorii vědomí hledat explanandum nové. Obrysy tohoto nového explananda podle Hříbka opět určil Dennett. ${ }^{2}$

1 Hř́ibek (2017, s. 217).

2 V textu budu často hovořit přímo o Dennettových názorech, protože i Hříbek chápe svou koncepci, rozvinutou v šesté kapitole knihy, jako obhajobu a extenzi Dennettovy teorie vědomí. 
Domnívám se, že takový odhad situace je možná až přiliš pesimistický. Jak se pokusím ukázat, navzdory velmi odlišné terminologii tu podle všeho netriviální názorový průnik mezi Dennettem a tradicí je. Díky němu je zde i určitá šance na shodu ohledně explananda teorie vědomí, jež můžeme chápat poměrně tradičně. Na druhé straně, Dennett a jeho obhájci a interpreti občas tvrdí věci, které, jak se zdá, tuto možnost shody opět zpochybňují. Mým závěrem tak bude, že reálná míra shody mezi táborem dennettovců a tradičněji orientovanými autory zůstává nejasná.

\section{Fenomenální vědomí a manifestní obraz světa}

Za „mainstream“ současné filozofie vědomí lze podle mě označit ty autory, kteří za explanandum teorie vědomí pokládají nagelovsky chápané fenomenální stavy: stavy organismů či entit, u nichž má smysl říci, že pro ně ,je nějaké“ se v těchto stavech nacházet. ${ }^{3}$ Filozofie mysli je plná debat o tom, jakou povahu tyto stavy mají. Jsou veskrze reprezentační? Jsou všudypřítomné, jak věří panpsychisté? Má k nim subjekt neomylný přístup? Ohledně odpovědí na tyto otázky nepanuje shoda. Jsem však přesvědčen, že tato neshoda v detailech jednotlivých teorií vědomí se nevylučuje se shodou na jejich společném explanandu. Stačí prostě vymezit to explanandum tak, aby se do něj rozdílná teoretická hlediska nepromítala. Přesně takový postup navrhuje Eric Schwitzgebel. Podle něj bychom měli fenomenální vědomí chápat „nevinně“ (innocently). Díky tomu se budeme moci, na jedné straně, široce shodnout na jeho existenci, na druhé straně se pak se vší vervou budeme moci pustit do debat o tom, jaké vlastnosti má a jak je nejlépe vysvětlit. Schwitzgebel postupuje metodou výčtu několika neproblematických př́kladů fenomenálně vědomých stavů, $\mathrm{k}$ nimž pak jako kontrastní skupinu uvede pár negativních př́íkladů - jevi̊, které zcela bezpečně stavy fenomenálního vědomí nejsou. Pak již lze jen doufat, že čtenář pochopí, co mají proponenti pojmu fenomenálního vědomí na mysli. K pozitivním př́íladům fenomenálních stavư řadí Schwitzgebel smyslové vjemy, představy, živé emoce a sny. Navzdory své různosti mají všechny tyto stavy nagelovskou what-it’s-like-ness. Negativními př́klady jsou sekrece růstového hormo-

3 Nagel (1974). 
nu, dispoziční znalosti, dlouhodobé záměry nebo reakce na maskované vizuální podněty v laboratoři. ${ }^{4}$

Mnoho Dennettových vyjádření se dá vykládat tak, že tuto nevinnou verzi fenomenálního vědomí přijímá. Např́íklad v knize Intuition Pumps ${ }^{5}$ pracuje se známým rozlišením, které na scénu uvedl Wilfrid Sellars. Jde o rozlišení mezi vědeckým obrazem světa a jeho „manifestním“ obrazem. ${ }^{6}$ Do manifestního obrazu světa patří barvy, zvuky, vůně apod. Naproti tomu vědecký obraz světa se skládá např́iklad z neuronů a jejich vzruchů. Dennett tvrdí, že lidová psychologie občas ze sellarsovské dichotomie nesprávně učiní triádu a k manifestnímu obrazu a vědeckému obrazu připojí ještě chybné lidové pojetí manifestního obrazu nějakého jevu. ${ }^{7}$ Tak naprríklad u svobodné vůle je jejím manifestním obrazem to, že se my lidé dokážeme učit novým způsobům chování, čímž rozšiřujeme svůj repertoár možných reakcí na výzvy prostředí. Vědeckým obrazem svobodné vůle jsou pak vědou odhalované neurální mechanismy, které flexibilní chování umožňují. Třetím prvkem je pak nesprávné lidové pojetí svobodné vůle: představa, že jsme zcela svobodní autoři svých činů, kteří se mohou rozhodovat zcela nezávisle na okolnostech jednání a na jeho kauzálních antecedentech.

Zkusme nyní podobnou triádu vyznačit u fenomenálního vědomí. Ve vědeckém obrazu světa mu odpovídají kaskády mozkových procesů. Nesprávné lidové pojetí manifestního obrazu vědomí spočívá v přesvědčení, že vědomí je neomylné, vždy přístupné jen z perspektivy první osoby, nerelační, neredukovatelné na neurální substrát apod. O takto pojatém „inflačním“ vědomí lze jistě mít oprávněné pochybnosti; Dennett je vyjádřil např́iklad ve svém klasickém článku „Quining qualia“. ${ }^{8}$ Co je ale tím třetím členem triády - správným manifestním pojetím vědomí? Podle mě je jím to, co Dennett (a Hř́ibek po jeho vzoru) nazývá prostě „zkušenost“.

Mou tezí je, že „zkušenost“, jejíž existenci jak Dennett, tak Hříbek přijímají, není nic jiného než Schwitzgebelovo nevinně chápané feno-

4 Schwitzgebel (2016).

5 Dennett (2013, s. 69-72).

6 Sellars (1962).

7 Dennett (2013, s. 355-56).

8 Dennett (1988). 
menální vědomí. A at’ už tomu nakonec budeme ř́íkat jakkoli, stěží to z našeho obrazu světa může vymizet. Je to naše jediná cesta k uchopení toho, co to vědomí vlastně je. Jen s pomocí vědeckého popisu světa nebo ze záznamů ve tř̌etí osobě bychom nikdy nepochopili, o čem je řeč. Mou druhou tezí pak je, že v tomto nevinném smyslu termín „fenomenální vědomí“ používá většina současných filozofư mysli. Přestože termín „fenomenální vědomí“ původně zpopularizoval Ned Block, který mu připsal určité typické vlastnosti a odlišil ho od „přístupového vědomi“", ${ }^{9}$ dnes se již málokdo drží pojmu fenomenálního vědomí v takto úzkém smyslu. Nevinně pojaté fenomenální vědomí v literatuře dominuje. Jsem proto toho názoru, že nevinné fenomenální vědomí či zkušenost můžeme prohlásit za hledané explanandum teorie vědomí. Shoda na explanandu je tudíž možná nejen v okruhu tradičně zaměřených teoretiků, kteří termín „fenomenální vědomí“ běžně používají, ale může se k ní připojit i Hříbek s Dennettem.

Přestože je fenomenální vědomí postulátem manifestního obrazu, neznamená to, že ho musíme zkoumat manifestními prostředky, například „introspekcí“. Jako explanans samozřejmě můžeme využít jakékoli prostředky empirické vědy. I kognitivní neurovědci a psychologové totiž chápou předmět vědy o vědomí (science of consciousness) výše popsaným způsobem. Dokladem budiž téměř jakýkoli text z těchto oborů, který se vědomím zabývá. Např́lklad: „Být vědomý znamená něco zakoušet - nacházet se v subjektivním, fenomenálním stavu a zakoušet, ,jaké to je“ něco vidět, slyšet zvuk, myslet myšlenku nebo prožívat nějakou emoci."10 Anebo: „Vědomí - jaké to je něco zakoušet - nepochybně představuje jeden z nejvýznamnějších vědeckých problémů současnosti“ (takto začíná projekt grantu ERC Consciousness: The Radical Plasticity Thesis, který nedávno řešili belgičtí kognitivní neurovědci pod vedením Axela Cleeremanse $\left.{ }^{11}\right)$. Takové chápání vědomí nejenže není v článcích současných neurovědců zřídkavé; ono je normou.

9 Block (1995).

10 Koch, Massimini, Boly \& Tononi (2016, s. 307); článek je nejaktuálnějším přehledem stavu výzkumu tzv. neurálních korelátů vědomí.

11 Viz http://axc.ulb.be/pages/radical-plasticity. K dalším příkladům textů vědců, kteří chápou vědomí jako fenomenální vědomí, viz Persuh (2018), Balsdon \& Clifford (2018), Mazzi, Savazzi \& Silvanto (2017), Jonkisz, Wierzchoń \& Binder (2017), Tsuchiya, Wilke, Frässle \& Lamme (2015). 
Není to ale tak, že zatímco Dennett s Hř́ibkem nabídli netechnický pojem zkušenosti, který může hrát roli manifestního obrazu vědomí, obhájci fenomenálních kvalit a obratu ,jaké to je být někým“ předkládají technický pojem zatížený balastem lidové psychologie a nezpracovaných teoretických předpokladi̊? Hř́ibek věc takto staví. Podle něj se příznivci fenomenálního vědomí nemohou dobrat společné neutrální půdy, na níž by své neshody o vědomí mohli probírat; vždy si nutně nerozumějí, protože od počátku do vědomí promítají své rozlišné představy. Podle mě taková obhajoba Dennetta neobstojí. Souhlasil bych s tím, že všechny běžně užívané metafory pro fenomenální vědomí jsou nedokonalé $\mathrm{v}$ tom smyslu, že se nekryjí s běžným užitím slov. Tak např́klad obrat „jaké to je být někým“ je v běžném životě používán nikoli pro popis momentálního vizuálního (zvukového atd.) prožitku, ale pro popis celé řady takových prožitků, které se dohromady pojí s nějakou životní situací nebo rolí. Mluvíme třeba o tom, jaké to je být astronautem. Přesto obrat ,jaké to je být někým" používáme i tehdy, chceme-li obrátit pozornost čtenáře právě na momentální obsahy vědomí. Naprosto totéž ale platí i o pojmu zkušenosti. I ten je v běžné řeči použiván trochu jinak, a to podobně jako „jaké to je být někým“ - mluvíme například o „dlouhodobé zkušenosti s používáním Androidu“. Oba pojmy jsou v rámci teorie vědomí do jisté míry technické. ${ }^{12}$ To ale - alespoň v mých očích - nesnižuje jejich užitečnost. To, co se takové termíny snaží postihnout, totiž nijak technické nebo umělé není: jde o prožívanou realitu vědomí v celé jeho pestrosti.

Tvářit se, že „zkušenost“ není obdobně umělý pojem jako „fenomenální vědomí", tedy není úplně poctivé; tenhle jednoduchý trik dennettovcům neprojde. Termíny „zkušenost“ a ,jaké to je“ ve skutečnosti můžeme pokládat za synonyma. ${ }^{13}$ Pokud se tedy Dennett a zbytek filozofu shodnou na tom, že existuje „zkušenost“, je vyhráno a krach hledání společného explananda teorie vědomí je odvrácen. ${ }^{14}$

12 Viz ale nesouhlasný názor ve Farrell (2016).

13 Tvrdí to např́klad Galen Strawson v přednášce One Hundred Years of Consciousness: A Long Training in Absurdity (předneseno mj. na katedře filozofie UPOL v květnu 2014). Viz též Strawson (2018).

14 Jak upozornil v konverzaci Juraj Hvorecký, pokud je nutné každé explanandum od samého počátku svázat s množinou teoretických postulátů, na nichž se jeho proponenti shodnou, pak je otázkou, zda někdy může dojít ke shodě na jakémkoli explanandu. 


\section{Nechytejme se zbytečně nálepek}

Hlavním zdrojem nedorozumění mezi dennettovci a mainstreamem filozofie vědomí se zdá být to, že ti první chápou pojem fenomenálního vědomí příliš úzce. ${ }^{15}$ Samotné používání termínů jako „fenomenální vědomí" a "fenomenální charakter“ nemusí nutně znamenat, že se jejich uživatel hlásí $\mathrm{k}$ ontologicky podezřelé teorii. Dobře je to vidět třeba na pracích Jesseho Prinze. Prinz obhajuje reduktivní realismus ohledně fenomenálního vědomí. ${ }^{16} \mathrm{~V}$ něm je obsažena teze, že fenomenální vědomí (v nevinném pojetí) sice existuje, ale ontologicky vzato je bezezbytku realizováno mozkovými procesy. Které procesy to přesně jsou, zatím nikdo neví; na materialistickém přesvědčení reduktivních realistů to ale nic nemění. Prinz nicméně zcela volně používá nejen materialisticky chápaný pojem fenomenálního vědomí, ale dokonce termín „kvália“. Ten Dennett, jak známo, vehementně odmítá. Prinz je však zároveň jedním z autorů, které Dennett chválí a vydává je za exemplární př́íklady toho, jak by se k teorii vědomí mělo přistupovat. Dokonce výslovně uvádí, že Prinzova teorie vědomí se v některých zásadních momentech podobá té jeho. ${ }^{17} \mathrm{Z}$ tohoto úhlu pohledu jsou rozdíly mezi Dennettem a Prinzem mnohem menší, než by se mohlo zdát z Hř́bkových (a Dennettových) výroků.

Beru si z toho ponaučení, že bychom neměli lpět na nálepkách a spíš bychom se vždy měli pořádně podívat, co se pod nimi skrývá. Povrchové terminologické rozdíly mohou zakrývat hlubší názorové shody a vstřícný interpretační postoj by to měl reflektovat.

\section{Eliminace a iluze}

V literatuře se lze často setkat $\mathrm{s}$ názorem, že Dennett nechce vědomí vysvětlit, ale př́mo eliminovat. Dennett se brání, že nic takového dělat nechce. Hříbek ho tedy vstř́ícně čte ne jako eliminativistu ohledně vědomí, ale pouze jako redukcionistu. Vědomí podle Dennetta existuje, ale

15 Srov. Blackmoreová (2006, s. 5-6).

16 Prinz (2016).

17 Dennett (2015, s. 1). 
není ničím jiným než koordinovanými mozkovými procesy. Potom se ale Dennett přece jen tolik neodchyluje od současné empiricky informované filozofie mysli, jak by se zdály naznačovat některé jeho výroky - shoduje se např́iklad se zmíněným Prinzem a jeho reduktivním realismem.

Dennett však na druhé straně občas ř́iká věci, které ho od současných teorií empiricky informované filozofie mysli vzdalují. Některá jeho tvrzení skutečně působí dojmem, že sice hovoří o „zkušenosti“, ale tu důkladně dekonstruuje a nakonec pod ní myslí něco úplně jiného než všichni ostatní. Jako by chvílemi koketoval s myšlenkou, že zkušenost je jen zdánlivá - že je druhem neodbytné iluze, že prožíváme fenomenální stavy. To je alespoň jeden způsob, jak si vykládat jeho obhajobu ,iluzionismu“ v teorii vědomí. ${ }^{18}$

Autorem tohoto termínu je filozof Keith Frankish. V jeho vymezení iluzionismus nepůsobí až tak radikálně. Jde prý o odmítnutí jisté koncepce toho, co jsou vjemy. ${ }^{19}$ Čili by mělo jít o nějaké systematické rozpracování Dennettovy kritiky „inflačních“ kválií. Iluzionismus se ale v některých momentech zdá jít za upřímný redukcionismus, například ten Prinzův, směrem k eliminativismu vědomí. Nejde jen o to, že samotný název nutně svádí k nedorozuměním. V duchu maximy představené v minulém oddíle jsem připravený nechytat se nálepek a hledat hlubší obsahové rysy dané teorie. Iluzionismus na mě přesto v některých momentech působí jako teorie, v níž se z prožívané zkušenosti stává mluvení a souzení o zkušenosti. Taková radikálně kognitivistická teorie by skutečně zaváněla silným revizionismem všech běžných představ o vědomí a zkušenosti, včetně odmítnutí fenomenálního vědomí i v jeho nevinné podobě. Shoda na explanandu teorie vědomí, dosažená výše, by se nám tak znovu začala rozpadat pod rukama. Dennett a další iluzionisté jako by přece jen chtěli tradiční explanandum teorie vědomí spíš odmítnout, respektive nahradit něčím jiným, než vysvětlit.

Prinz je př́ikladem čtenáře, který si iluzionismus vyložil právě takto: žádnou zkušenost prý podle Dennetta a Frankishe nemáme. Máme jen přesvědčení o zkušenosti, která jsou systematicky chybná. Chybně se nám totiž zdá, jako bychom podstupovali stavy, které mají nagelovské

18 Dennett (2016).

19 Frankish (2016, s. 9). 
jaké to je“. ${ }^{20}$ To je nesmírně poučné. Autor s hlubokou znalostí Dennettova díla dospěl $\mathrm{k}$ takovému čtení ne kvůli nálepkám, ale na základě poctivé obsahové analýzy Dennettových a Frankishových děl. Hř́ibkova verze iluzionismu bohužel dojem revizionismu vủbec nepomáhá zaplašit. Vycházím z referátu na nedávném česko-polském workshopu o možnostech naturalizace vědomí, který Hř́ibek zakončil slovy: „Možná bychom měli výzkum vědomí pojmout jinak - jako zkoumání fyzických vlastností, které nás nutí myslet si a ř́kat, že je nějaké podstupovat zkušenosti. “" Rozumím tomu tak, že to co se běžně chápe jako vědomí či zkušenost z Hř́ibkova projektu vypadne jako nadbytečné.

Zkrátka, nemohu se zbavit dojmu, že s námi iluzionisté hrají podivnou hru. Její základní tahy bych shrnul následujícím způsobem: (1) „Zkušenost existuje“ (Dennett, Hříbek, Frankish) - (2) „Vjemy v každodenním smyslu" (sensations in the everyday sense) existují také (Frankish) ${ }^{22}$ (3) „Bolesti existují, ale jsou něco jiného než vjemy (sensations) - spíše něco jako soudy“ (Hř́bek) 23 - (4) Tyto soudy jsou systematicky nepravdivé; jsou kauzálním důsledkem neurálních událostí, které „nás nutí myslet si a říkat, že je nějaké podstupovat zkušenosti“ (Hř́bek, citované vyjádření). Někde mezi tahy (2) a (3) se odehraje zásadní posun, při němž jako by se iluzionistům z pojmu vědomí vytratilo to, co si pod ním představujeme my ostatní. Iluzionista nejprve na oko uzná, že běžné vjemy a prožitky existují. Vzápětí z nich ale udělá něco jiného - něco jako soudy nebo přesvědčení. $V$ rámci iluzionistické hry se tak opakovaně stáváme svědky toho, jak se z rozumného cíle - dejme tomu, z odmítnutí „inflačních“ kválií - stává absurdní podnik: odmítání zkušenosti, jak ji známe, a její nahrazení zvláštními surogáty. Tato hra mate nejen mě, ale jak jsem zjistil četbou i řadu dalších lidí, včetně čelních autorit současné vědy o vědomí. Dokladem budiž např́klad rozhovor, který Susan Blackmoreová pořídila s Patricií a Paulem Churchlandovými. Oba dotázaní se shodují v tom, že Dennett úspěšně rozbil výmysly typu imateriálních kválií. Patricia Churchlandová ale ihned dodává, že Dennett jí místy

20 Prinz (2016).

21 „Comments on Jakub Mihálik's ,In Search of the Protophenomenal““, workshop Naturalistic Approaches to Content and Consciousness II, Filosofický ústav AV ČR, 18. 9. 2017.

22 Frankish (2016, s. 9).

23 Hř́bek (2017, s. 271). 
zní jako zatvrzelý behaviorista, který chce popřít realitu běžné vědomé zkušenosti. Svou odpověd’ končí přiznáním, že si vlastně „není tak úplně jistá, co chce Dennett ve skutečnosti ř́ct“.. ${ }^{24}$

Označit něco za pouhou iluzi může být výrazem toho, že chceme udělat krátký proces s entitami, které nezapadají do našeho oblíbeného explanačního rámce. Domnívám se, že tomuto lákavému pokušení by současní materialisté, k nimž se počítám, měli odolat. Hledání nových způsobů vysvětlování zatím stále ještě dost záhadného fenomenálního vědomí mi připadá jako mnohem smysluplnější počin. Na druhé straně, nikdo samozřejmě nepopírá, že některé vlastnosti prožívané zkušenosti jsou systematicky iluzorní. Např́klad vizuální zkušenost se nám systematicky jeví jako bohatší, než ve skutečnosti je. ${ }^{25} \mathrm{~V}$ tomto omezeném smyslu má řeč o iluzích vědomí dobrý smysl; Prinz proto navrhuje, že by se místo „illusionism“ mohlo ř́kat „mistakism“. ${ }^{26}$ Avšak z toho, že se můžeme mýlit i v těch aspektech zkušenosti, které nám subjektivně připadají jako zřejmé, lze jen sotva vyvodit, že všechny aspekty zkušenosti jsou iluzorní. Pokud toto iluzionisté tvrdí, měli by nám vysvětlit, jak se lze k tak dalekosáhlé skepsi dopracovat.

\section{"Soudy"}

Dennett sice oprávněně zdůrazňuje, že stvořit něco, co má jen zdánlivě nějaké vlastnosti, bývá leckdy jednodušší než stvořit něco, co má ty vlastnosti doopravdy. Na druhé straně, vysvětlení všeobjímající omylnosti zkušenosti je apriorně zatíženo silným handicapem. Je totiž snazší lidi oklamat, než je přesvědčit, že byli oklamáni (jak praví výrok neznámého autora, mylně připisovaný Marku Twainovi). A přesvědčit je, že se neustále mýlí i v tom, že podstupují kvalitativní zkušenost, zní jako projekt předem odsouzený k zániku. Méně ambiciózní, ale i tak mimořádně zajímavý projekt by byl vysvětlit, v jakém smyslu běžná zkušenost obsahuje „soudy“. Bohužel ani v tomto nám Dennett a Hř́ibek zatím moc nepomohou: žádné podrobné vysvětlení soudové povahy vědomí jsem v knihách ani jednoho z nich neobjevil. O tom, že implicitní sou-

24 Blackmoreová (2006, s. 60).

25 Viz Hříbek (2017, s. 265).

26 Prinz (2016, s. 194). 
dy tvoří součást vědomého smyslového vnímání, hovořil již Descartes. Descartovy soudy ale nejsou autoreferenční jako u Dennetta a Hř́bka. Descartes upozorňoval na to, že vjemy těles umístěných v prostoru mohou jako jednu ze svých složek obsahovat i nevyřčené soudy např́íklad o vzdálenosti těchto těles od mluvčího. ${ }^{27}$ Dennett $\mathbf{s}$ Hř́bkem, nakolik jim rozumím, mají na mysli to, že bolest je spíš něco jako soud „Právě cítím bolest“ a chutnání jablka něco jako soud „Právě chutnám jablko“. Což zní velmi podobně jako teorie vědomí vyššího řádu (HOT), jejímž autorem je David Rosenthal (2005). I v této teorii hraje ústřední roli myšlenka $\mathrm{v}$ první osobě, která specifikuje obsah vědomě prožívaného kvalitativního stavu.

Rosenthal ale nijak nepopírá, že pokud je vhodná myšlenka vyššího řádu na scéně, fenomenální stavy skutečně proživáme; je to reduktivní realista. Chtějí jít Dennett a Hř́ibek ještě dál a tvrdit, že místo reálně prožívané bolesti ve skutečnosti jen činíme soud, který vyvolává iluzi tohoto kvalitativního stavu? Je jejich iluzionismus až tak radikální? Pete Mandik, další dennettovec, se domnívá, že Dennetta takto radikálně vykládat nemusíme. Podle Mandika (2015) Dennett zastává „first-person operationalism“ (FPO). Toto pojetí uznává, že zkušenostní stavy reálně existují, ale zároveň tvrdí, že nikdy nejsou nezávislé na přesvědčeních a soudech těch, kdo se v těchto stavech nacházejí. Soudy tedy nejsou náhražkami zkušeností, ale tyto zkušenosti jen spoluustavují.

Toto mírnější čtení nejen působí plauzibilnějším dojmem než naprostá eliminace vjemů ve prospěch soudů, ale je též dobře slučitelné s Dennettovou teorií sond, kterou Hříbek představuje v kapitole 6.5.1 své knihy. Podle této teorie nemá žádný vědomý stav svi̊j obsah ustavený nezávisle na otázkách o zkušenosti, které klademe subjektu, a na jeho odpovědích na ně. Přesto si správností Mandikova výkladu nejsem zcela jistý. Jak upozorňoval již Carl Stumpf, stavy vědomí vždy měříme nepřímo; přímo měříme jen soudy subjektu o těchto stavech.$^{28}$ Dennett jako by někdy bral tento fakt až př́liš vážně. Právě v jeho př́lišném zdůraz-

27 James Hill (2012, kap. 8) předložil originální čtení Descarta jako obhájce systematické role souzení v rámci vědomého vnímání.

28 Stumpfovu teorii vědomí v tomto smyslu vykládal Robin Rollinger v příspěvku „Stumpf on Relations in Tonal Consciousness“ předneseném na workshopu Classical and Contemporary Concepts of Mind, který proběhl na Filosofickém ústavu AV ČR 1. 11. 2016. 
ňování se objevuje onen „behaviorismus“, o kterém mluvila v citované pasáží Churchlandová. Jakoby se někdy v jeho rukou z prožitku stal jen soud či výpověd' o tomto prožitku. ${ }^{29}$

I po Hříbkově pečlivé práci tak stále zůstává nejasné, jak radikálně máme Dennettovu kognitivní teorii vědomí chápat. Chce Dennett jen říct v duchu Mandikova FPO, že soud se na proživané zkušenosti konstitutivně podílí? Nebo chce běžné prožitky soudy zcela nahradit?

\section{Závěrem}

Dennett se občas vyjadřuje tak nejednoznačně, že jeho výrokům velmi svědčí trpělivá péče vstřrícných a pozorných interpretů jako jsou Hř́bek, Frankish nebo Mandik. I přes jejich interpretační výkony si ale stále nejsem jistý, jak je třeba Dennettovu teorii vědomí chápat. Především nepokládám za zřejmé, kolik z běžného pojmu zkušenosti chce Dennett ve své teorii podržet a co je již připraven hodit přes palubu. Přimlouval bych se proto za soustředěné debaty o tom, co je iluzionismus jakožto teorie vědomí a do jaké míry vyžaduje revizi běžného pojetí zkušenosti. Dokud neproběhnou, reálná míra shody mezi dennettovským táborem a tradičněji orientovanými autory zůstane nejasná - a s ní i to, zda existuje všeobecně sdílené explanandum teorie vědomí, nebo nikoli.

\section{Literatura}

Balsdon, T., \& Clifford, C. W. G. (2018): „Visual Processing: Conscious until Proven Otherwise." Royal Society Open Science 5 (1). DOI: $10.1098 /$ rsos.171783.

Blackmoreová, S. (2006): Conversations on Consciousness: What the Best Minds Think about the Brain, Free Will, and What It Means to Be Human. Oxford University Press, Oxford.

Block, N. (1995): „On A Confusion About a Function of Consciousness.“ Behavioral and Brain Sciences 18: 227-47.

29 Tento dojem ve mně posilují například Dennettovy úvahy o „heterofenomenologii“. Hříbek je subtilně vykládá v kapitole 6.4 své knihy. Viz též Dennett (2007). 
Dennett, D. (1988): „Quining Qualia.“ In Consciousness in Contemporary Science, eds. A. Marcel \& E. Bisiach, Oxford University Press, New York, 1988, s. 42-77.

Dennett, D. (2007): „Heterophenomenology Reconsidered.“ Phenomenology and the Cognitive Sciences 6 (1-2): 247-70.

Dennett, D. (2013): Intuition Pumps. Allen Lane, London.

Dennett, D. (2015): „Why and How Does Consciousness Seem the Way it Seems?" In Open MIND, eds. T. Metzinger \& J. M. Windt, Frankfurt am Main, 2015, s. 1-11. DOI: 10.15502/9783958570245.

Dennett, D. (2016): „Illusionism as the Obvious Default Theory of Consciousness." Journal of Consciousness Studies 23 (11-12): 65-72.

Farrell, J. (2016): „What It Is Like' Talk is not Technical Talk.“ Journal of Consciousness Studies 23 (9-10): 50-65.

Frankish, K. (2016): „Editorial Introduction.“ Journal of Consciousness Studies 23 (11-12): 9-10.

Hill, J. (2012): Descartes and the Doubting Mind. Continuum, London/ New York.

Hř́bek, T. (2017): Jaké to je, nebo o čem to je? Místo vědomí v materiálním světě. Filosofia, Praha.

Jonkisz, J., Wierzchon, M. \& Binder, M. (2017): „Four-Dimensional Graded Consciousness." Frontiers in Psychology 8, art. 420. DOI: 10.3389/fpsyg.2017.00420.

Koch, Ch., Massimini, M., Boly, M. \& Tononi, G. (2016): „Neural Correlates of Consciousness: Progress and Problems." Nature Reviews Neuroscience 17 (5): 307-22.

Mandik, P. (2015): „Conscious-State Anti-Realism.“ In Content and Consciousness Revisited. With Replies by Daniel Dennett, eds. C. Muñoz-Suárez \& F. De Brigard, Springer, Cham, 2015, 185-97.

Mazzi, C., Savazzi, S. \& Silvanto, J. (2017): „On the 'Blindness, of Blindsight: What is the Evidence for Phenomenal Awareness in the Ab- 
sence of Primary Visual Cortex (V1)?" Neuropsychologia. Epub ahead of print. DOI: 10.1016/j.neuropsychologia.2017.10.029.

Nagel, T. (1974): „What Is It Like to Be a Bat?“ The Philosophical Review 83 (4): 435-450.

Persuh, M. (2018): „The Fata Morgana of Unconscious Perception.“

Frontiers in Human Neuroscience 12, art. 120. DOI: 10.3389/ fnhum.2018.00120.

Prinz, J. (2016): „Against Illusionism.“ Journal of Consciousness Studies 23 (11-12): 186-96.

Rosenthal, D. (2005): Consciousness and Mind. Oxford University Press, Oxford.

Sellars, W. S. (1962): „Philosophy and the Scientific Image of Man.“ In Frontiers of Science and Philosophy, ed. R. Colodny, University of Pittsburgh Press, Pittsburgh, 1962, s. 35-78.

Schwitzgebel, E. (2016): „Phenomenal Consciousness, Defined and Defended as Innocently as I Can Manage." Journal of Consciousness Studies 23 (11-12): 224-35.

Strawson, G. (2018) „The Consciousness Deniers.“ The New York Review of Books, 13. 3. 2018. Dostupné z: <http://www.nybooks. com/daily/2018/03/13/the-consciousness-deniers/> .

Tsuchiya, N., Wilke, M., Frässle, S., \& Lamme, V. A. F. (2015). „No-Report Paradigms: Extracting the True Neural Correlates of Consciousness." Trends in Cognitive Sciences 19 (12): 757-770.

\begin{abstract}
Explanandum of the theory of consciousness: no consensus in sight?

The text critically assesses the claims about phenomenal consciousness contained in the sixth chapter of Tomáš Hř́bek's book What Is it Like, or What Is it about? My starting point is Eric Schwitzgebel's thesis that we can define phenomenal consciousness in such a neutral and minimalistic way that it's existence can be accepted by theoreticians of consciousness of very different stripes. Hříbek does not share this conviction but I try to show that his reasoning is flawed. Consi-
\end{abstract}


derable attention is devoted to Daniel Dennett's views on the nature of consciousness, especially to "illusionism" as a theory of consciousness. I regard it as a theory with very unclear content, and suggest that philosophers of consciousness discuss its pros and cons extensively.

Marvan, T. (2017): „Explanandum teorie vědomí: marné hledání konsenzu?“ Filosofie dnes 9(2): 60-73. Dostupné z www.filosofiednes.ff.uhk.cz 